\title{
MIS 3 marine and lacustrine sediments at Kriegers Flak, southwestern Baltic Sea
}

\author{
JOHANNA ANJAR, NICOLAJ KROG LARSEN, SVANTE BJÖRCK, LENA ADRIELSSON AND HELENA L. FILIPSSON
}

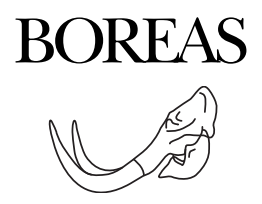

\begin{abstract}
Anjar, J., Larsen, N. K., Björck, S., Adrielsson, L. \& Filipsson, H. L. 2010 (April): MIS 3 marine and lacustrine sediments at Kriegers Flak, southwestern Baltic Sea. Boreas, Vol. 39, pp. 360-366. 10.1111/j.1502-3885. 2010.00139.x. ISSN 0300-9483.

Sediment cores from the Kriegers Flak area in the southwestern Baltic Sea show a distinct lithological succession, starting with a lower diamict that is overlain by a $c .10 \mathrm{~m}$ thick clay unit that contains peat, gyttja and other organic remains. On top follows an upper diamict that is inter-layered with sorted sediments and overlain by an upward-coarsening sequence with molluscs. In this paper we focus on the clay unit, which has been subdivided into three subunits: (A) lower clay with benthic foraminifera and with diamict beds in the lower part; (B) thin beds of gyttja and peat, which have been radiocarbon-dated to $31-35{ }^{14} \mathrm{C}$ kyr BP (c. 36-41 cal. kyr BP); and (C) upper clay unit. Based on the preliminary results we suggest the following depositional model: fine-grained sediments interbedded with diamict in the lower part (subunit A) were deposited in a brackish basin during a retreat of the Scandinavian Ice Sheet, probably during the Middle Weichselian. Around $40 \mathrm{kyr}$ BP the area turned into a wetland with small ponds (subunit B). A transgression, possibly caused by the damming of the Baltic Basin during the Kattegat advance at $29 \mathrm{kyr}$ BP, led to the deposition of massive clay (subunit $\mathrm{C}$ ). The data presented here provide new information about the paleoenvironmental changes occurring in the Baltic Basin following the Middle Weichselian glaciation.
\end{abstract}

Johanna Anjar (e-mail: Johanna.Anjar@geol.lu.se), Nicolaj Krog Larsen, Svante Björck, Lena Adrielsson and Helena L. Filipsson, GeoBiosphere Science Centre, Department of Geology, Quaternary Sciences, Sölvegatan 12, SE-223 62 Lund, Sweden; received 8th January 2009, accepted 3rd December 2009

Marine Isotope Stage 3 (MIS 3, 60-25 kyr BP) in the Northern Hemisphere is characterized by an interstadial climate punctuated by abrupt climate shifts, the so-called Dansgaard-Oeschger cycles (e.g. Dansgaard et al. 1993; Clement \& Peterson 2008). The generally warm interstadial climate during MIS 3 resulted in a significantly reduced or completely absent Scandinavian Ice Sheet, as reported from studies in southern Sweden and Bornholm (Kjær et al. 2006), northern Sweden (Hättestrand 2008), south and central Sweden and western Finland (Ukkonen et al. 2007; Wohlfarth 2009), northern Finland (Helmens et al. 2000, 2007) and western Norway (Mangerud et al. 2003). These icefree conditions were interrupted at the beginning and end of MIS 3 by two major ice advances that reached as far as Denmark, namely the Ristinge advance at $c$. 55-50 kyr BP and the Kattegat advance at c. 29-27 kyr BP (Houmark-Nielsen 2003, 2007; Houmark-Nielsen \& Kjær 2003; Kjær et al. 2006; Larsen et al. 2009a, b). A third ice advance, the Klintholm advance, has been proposed to have taken place c. 35-33 kyr BP (Houmark-Nielsen \& Kjær 2003), but the timing of this advance is still under debate (e.g. Ukkonen et al. 2007).

The Middle Weichselian history of the southwestern part of the Baltic Basin is largely unknown. Seismic studies reveal a complex pattern of glacially incised valleys in the Arkona Basin, in Hanö Bay (Flodén et al. 1997) and in the Gotland Basin (Bjerkéus et al. 1994; Flodén et al. 1997) (Fig. 1A, B). Marine clay has been described from two cores on the northeastern slope of Kriegers Flak (Klingberg 1998) (Fig. 1B). Radiocarbon dating of benthic foraminifera (Elphidium excavatum and Elphi- dium albiumbilicatum) found in this clay gave infinite ages ( $>40 \mathrm{kyr}$ BP), and the clay was therefore suggested to be of Late Saalian, Early Eemian or Early Weichselian age (Klingberg 1998). Middle Weichselian sediments have been identified on Møn in southeastern Denmark, on Rügen in northern Germany (Steinich 1992; Houmark-Nielsen 1994; Panzig 1997), and in western Latvia (Saks et al. 2007). On Møn, a fining-upward sequence dated to c. $50 \mathrm{kyr}$ BP indicates a shift from a glaciofluvial to a glaciolacustrine or lacustrine environment (Houmark-Nielsen 1994). On Rügen, sediments from the same time period have been interpreted as marine clays containing reworked Eemian sediments with benthic foraminifera (Steinich 1992; Panzig 1997), and in western Latvia, marine sand has been OSLdated to 45-43 kyr BP (Saks et al. 2007). It has been suggested that the Baltic Sea was connected to the Kattegat through the Esrum/Alnarp valley during MIS 3 (Fig. 1) (Lagerlund 1987; Andrén \& Wannäs 1988; HoumarkNielsen \& Kjær 2003). This valley is presently filled with sediments, but has a bedrock threshold at $60 \mathrm{~m}$ below sea level (b.s.l.), which makes an open Esrum/Alnarp valley the lowest threshold between the Baltic Sea basin and the Kattegat strait. Here we present a stratigraphy of Kriegers Flak and discuss the implications for the glacial and palaeoenvironmental history of the southwestern Baltic during MIS 3.

\section{Methods}

In this study we use sediment descriptions (provided by the company GEO) of nine geotechnical drill-cores from a wind-turbine project at Kriegers Flak, $30 \mathrm{~km}$ south of Trelleborg (Figs 1B, 2). In addition, we performed more 


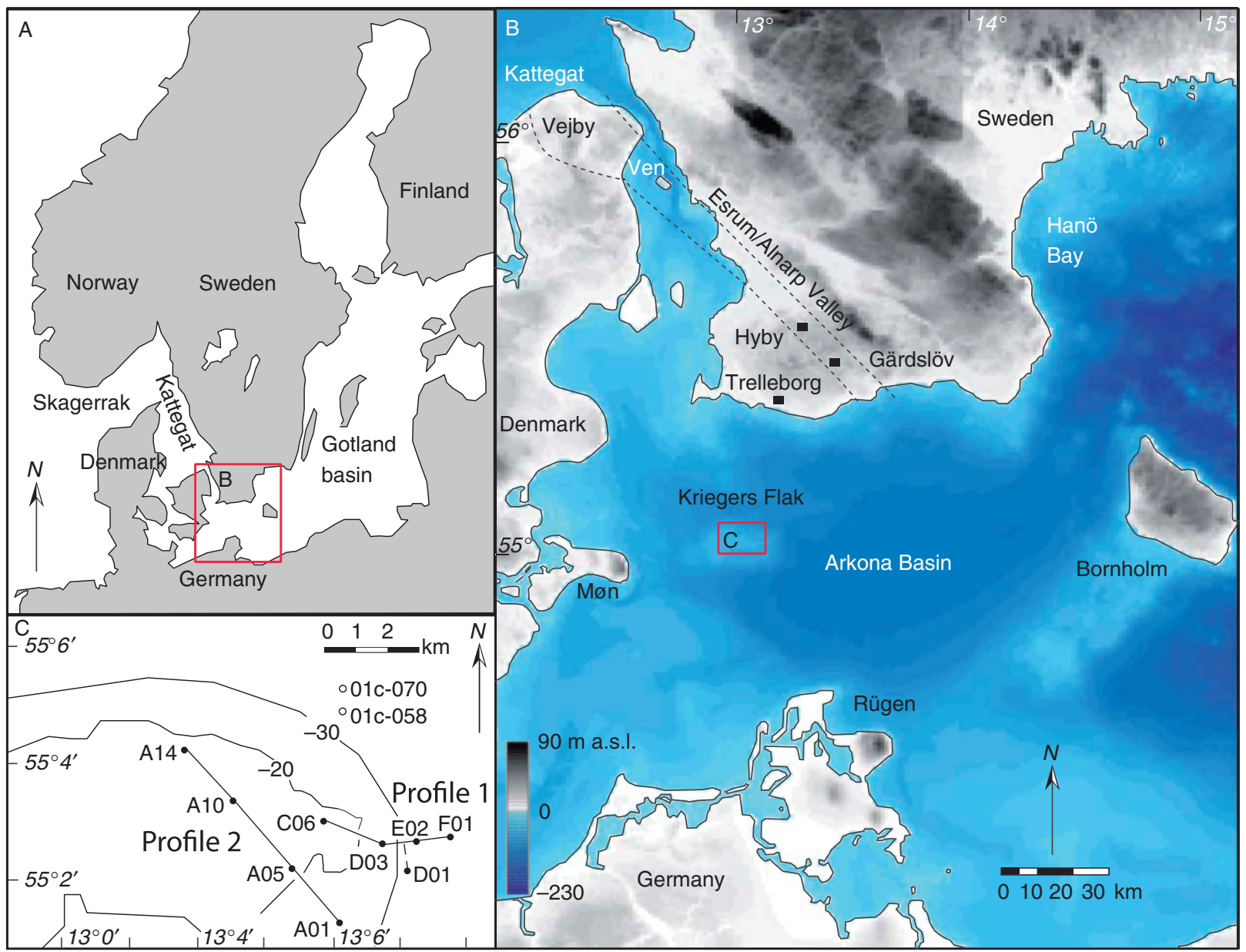

Fig. 1. A. Overview map of the Baltic Sea region. B. Localities mentioned in the text. Bathymetry from Seifert et al. (2001). C. Locations of the cores from Kriegers Flak investigated in this study and of the cores from Klingberg (1998).

detailed studies on core E02 (Figs 2, 3) in order to confirm the interpretations made by GEO. Four samples were taken from E02 to search for benthic foraminifera, and another four from core D03 to search for shell fragments. These sediment samples were washed over a $63-\mu \mathrm{m}$ screen, treated with sodiumdiphosphate $\left(\mathrm{Na}_{4} \mathrm{P}_{2} \mathrm{O}_{7}\right)$ during sieving to disintegrate sediment aggregates, dried at room temperature and surveyed for their foraminiferal and macrofossil content. Four bulk radiocarbon dates from cores D03, D01 and $\mathrm{E} 02$, one radiocarbon date on moss fragments from core $\mathrm{C} 06$ and a compilation of published (Esrum/Alnarp valley; Miller 1977) and unpublished (Hanö Bay; Björck \& Dennegård 1988 and Björck et al. 1990) radiocarbon dates (Table 1) provide a chronological framework. The radiocarbon dates presented here were calibrated according to Fairbanks et al. (2005; http://radiocarbon.ldeo. columbia.edu/research/radcarbcal.htm).

\section{Results}

Out of 40 geotechnical drill-cores from Kriegers Flak we chose nine cores from the eastern part because they contain a $c .10 \mathrm{~m}$ thick sequence consisting mainly of clay beneath a diamict unit (Figs 1C,2). The sediments in these cores consist of a 3-16 m thick lower diamict unit, which directly overlies the Cretaceous-Paleogene bedrock in most of the cores. Above follows a $2.8-14.5 \mathrm{~m}$ thick clay unit, which is overlain by a $1-17 \mathrm{~m}$ thick unit consisting of diamict beds inter-layered with sorted sediments. The uppermost sediments consist of a $0.4-7 \mathrm{~m}$ thick upward-coarsening sequence with molluscs. The genetic interpretation of the lower and upper diamict units and of the uppermost sorted sediments will be presented elsewhere. Here, we focus on the clay unit with its interstadial sediments.

\section{The interstadial sediments}

Description. - The clay unit consists of silty clay, in places interbedded with layers of sand, silt and organic sediments (Figs 2, 3). It has been subdivided into three subunits, A-C.

Subunit A is $2-6 \mathrm{~m}$ thick and consists mainly of massive clay, except for the lowermost part, where the clay 


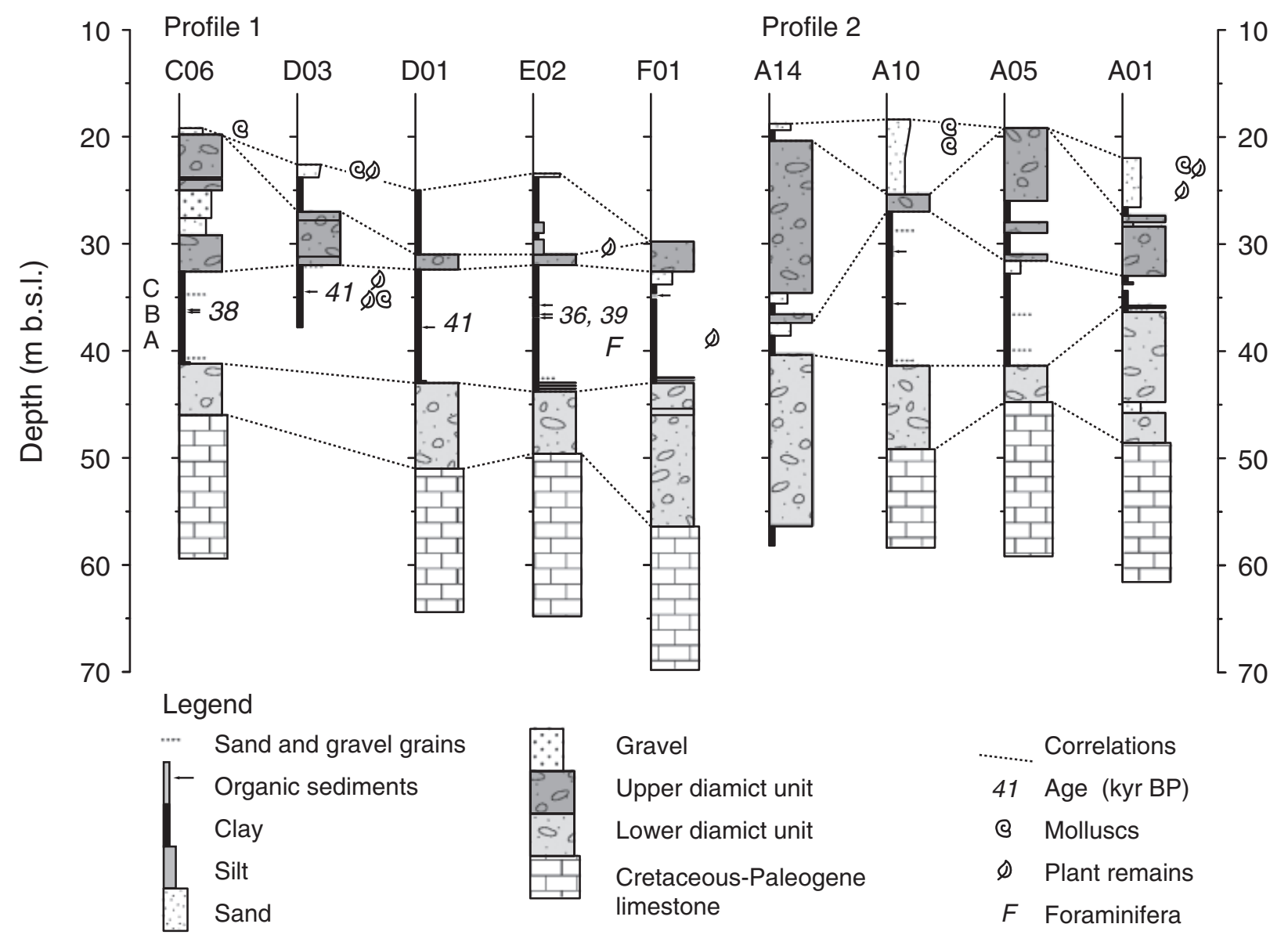

Fig. 2. Lithostratigraphic logs of the sediment cores from Kriegers Flak. Subunits A-C with clays, gyttja and peat were recorded between two diamict units.

contains grains of sand and gravel and is inter-layered with centimetre-thin diamict beds. Well-preserved benthic foraminifera were identified at $40 \mathrm{~m}$ b.s.l. in E02, and initial investigations indicate a low-diversity foraminifera fauna.

Subunit B is $0.07-4.5 \mathrm{~m}$ thick and consists of clay inter-layered with beds of organic sediments that were identified in the middle parts of five of the investigated cores (A10, C06, D01, E02 and F01) between 30 and $38 \mathrm{~m}$ b.s.l. In D01, a $7 \mathrm{~cm}$ thick peat layer was dated to c. 41 cal. kyr BP, and in C06 moss fragments were dated to 38 cal. kyr BP (Table 1). E02 contains three organic beds consisting of brown, calcareous clay gyttja, and the lowermost beds were radiocarbon-dated to $c .39$ and 36 cal. kyr BP, respectively (Fig. 3, Table 1). In core D03, subunit B consists of $1.5 \mathrm{~m}$ of clay and sandy clay with fragile limnic shell fragments identified as Sphaerium sp., Pisidium sp., Valvata piscinalis and Lymnaea pereger. The identifications are, however, uncertain owing to the highly fragmented appearance of these shells. An organic-rich laminae situated above the shell-rich interval at $34.5 \mathrm{~m}$ b.s.l. was radiocarbon dated to 41 cal. kyr BP (Fig. 3, Table 1).
Subunit $\mathrm{C}$ is the uppermost part of the clay succession and overlies the organic beds of subunit B. It is $2-5 \mathrm{~m}$ thick and consists of massive clay, but its uppermost part contains some sand and gravel.

Interpretation. - The clays of subunit A indicate deposition in a low-energy environment and probably also a low organic production. Diamict beds and dispersed grains of sand and gravel in the lower part are interpreted as debris flows and ice-rafted debris, indicating proximity to an ice margin. Benthic foraminifera were not found in the lower part but appear further up. The low diversity of the foraminiferal assemblage suggests brackish conditions during at least parts of the deposition period.

The calcareous clay gyttja of subunit B (in core E02) and the limnic shell fragments (in core D03) reflect deposition in a lacustrine environment, whereas the peat and moss fragments (recovered in cores D01 and C06, respectively), which seem to be contemporaneous with the clay gyttja, point to a terrestrial setting. The preservation of fragile limnic shell fragments in D03 indicates that they have not been redeposited. The 

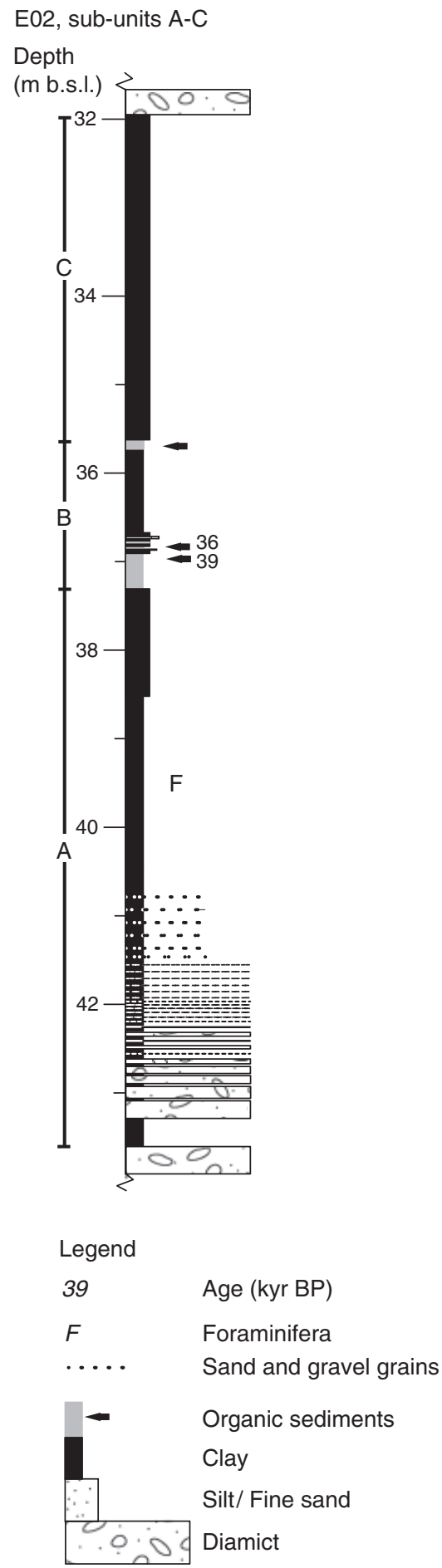

Fig. 3. Detailed lithological $\log$ of subunits A-C in core E02.

alternations between organic and inorganic sediments and peat suggest deposition in smaller, local lake basins as opposed to in a larger, glacially influenced basin. This scenario would imply that terrestrial areas, possibly with wetlands and smaller lakes, were uncovered during a falling relative sea level in the Baltic Basin. The radiocarbon dates give an age of 41-36 kyr BP for this subunit.

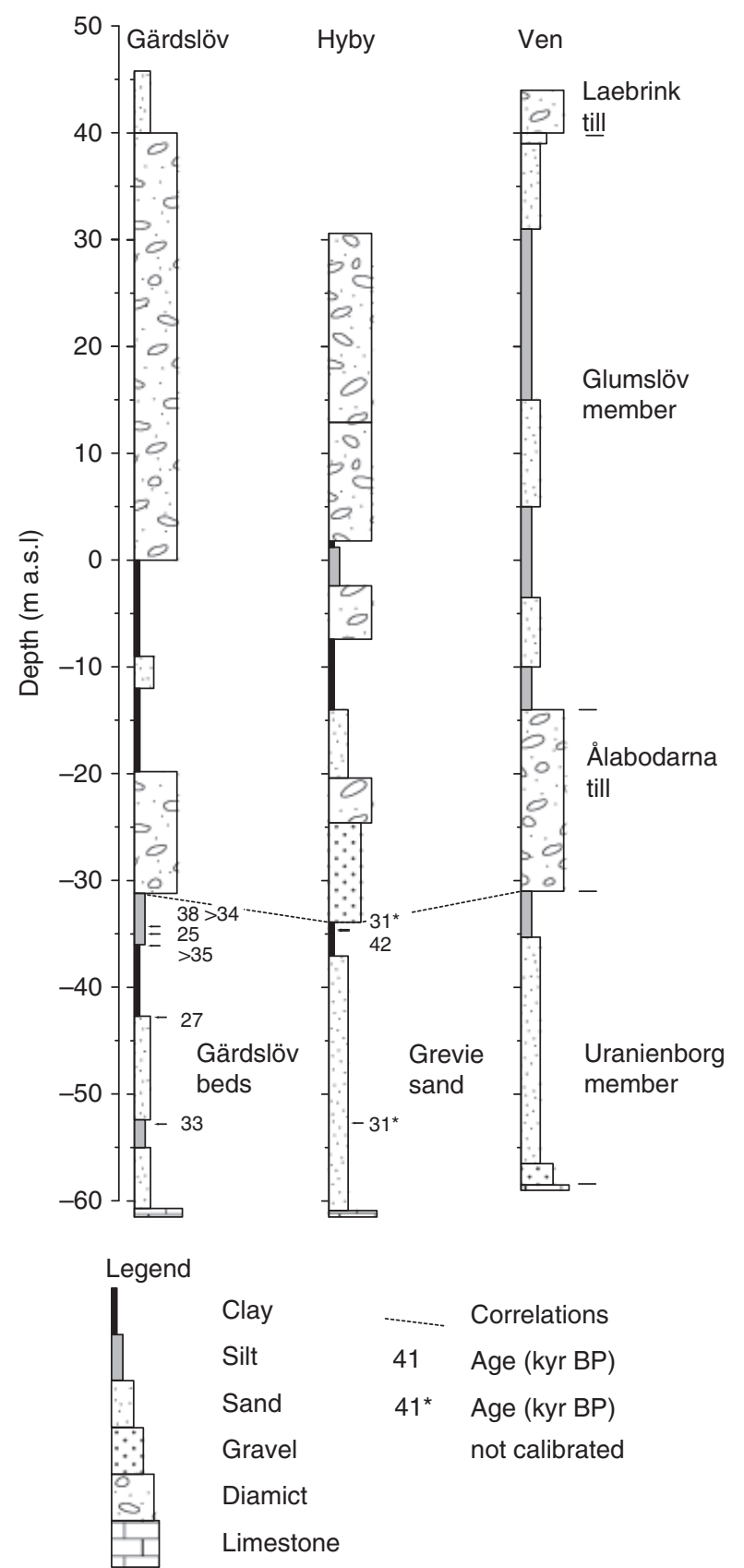

Fig. 4. Lithological logs of the Gärdslöv and Hyby cores (Nilsson 1973; Miller 1977) from the Alnarp Valley and of core site 17 on Ven (Adrielsson 1984).

The clay of subunit $\mathrm{C}$ indicates a shift from subaerial conditions with smaller ponds to sedimentation in a deeper basin. The large clasts found in the upper part of subunit $\mathrm{C}$ are interpreted as ice-rafted debris deposited by icebergs emanating from an advancing Scandinavian Ice Sheet.

\section{Discussion}

The presence of marine-brackish sediments (subunit A) in the Kriegers Flak area, the existence of a wetland with small isolated lake basins around 41-36 cal. kyr 
Table 1. Compilation of radiocarbon dates from Kriegers Flak and the Esrum/Alnarp Valley: (1) This study; (2) Miller (1977); (3) Björck et al. (1990). Calibrated using Fairbanks et al.'s (2005) calibration (http://radiocarbon.ldeo.columbia.edu/research/radcarbcal.htm).

\begin{tabular}{|c|c|c|c|c|c|c|c|c|}
\hline Borehole & Depth (m b.s.1.) & Latitude & Longitude & Lab no. & $\begin{array}{l}\text { Radiocarbon } \\
\text { age (yr) }\end{array}$ & $\begin{array}{l}\text { Calibrated } \\
\text { age }(\mathrm{kyr}, \pm 1 \sigma)\end{array}$ & Unit & Reference \\
\hline Kriegers Flak C06 & 36.2 & $55^{\circ} 3^{\prime} 2^{\prime \prime}$ & $13^{\circ} 7^{\prime} 47^{\prime \prime}$ & LuS 8669 & $32600 \pm 400$ & $38 \pm 0.4$ & Subunit B & 1 \\
\hline Kriegers Flak D03 & 34.5 & $55^{\circ} 2^{\prime} 39^{\prime \prime}$ & $13^{\circ} 9^{\prime} 31^{\prime \prime}$ & LuS 8670 & $35200 \pm 600$ & $41 \pm 0.6$ & Subunit B & 1 \\
\hline Kriegers Flak D01 & 37.7 & $55^{\circ} 2^{\prime} 11^{\prime \prime}$ & $13^{\circ} 10^{\prime} 15^{\prime \prime}$ & LuS 7439 & $35250 \pm 500$ & $41 \pm 0.5$ & Subunit B & 1 \\
\hline Kriegers Flak E02 & 36.8 & $55^{\circ} 2^{\prime} 44^{\prime \prime}$ & $13^{\circ} 10^{\prime} 31^{\prime \prime}$ & LuS 8454 & $30800 \pm 350$ & $36 \pm 0.4$ & Subunit B & 1 \\
\hline Kriegers Flak E02 & 37 & $55^{\circ} 2^{\prime} 44^{\prime \prime}$ & $13^{\circ} 10^{\prime} 31^{\prime \prime}$ & LuS 7440 & $33850 \pm 600$ & $39 \pm 0.6$ & Subunit B & 1 \\
\hline Hanö Bay H29 & 60.3 & $55^{\circ} 39^{\prime} 53^{\prime \prime}$ & $14^{\circ} 43^{\prime} 63^{\prime \prime}$ & Lu 3075 & $>35000$ & & Unit ReW & 1,3 \\
\hline Hanö Bay H29 & $60.4-60.5$ & $55^{\circ} 39^{\prime} 53^{\prime \prime}$ & $14^{\circ} 43^{\prime} 63^{\prime \prime}$ & Lu 3076 & $>44000$ & & Unit ReW & 1,3 \\
\hline Hanö Bay H29 & 60.7 & $55^{\circ} 39^{\prime} 53^{\prime \prime}$ & $14^{\circ} 43^{\prime} 63^{\prime \prime}$ & Lu 3077 & $>34000$ & & Unit ReW & 1,3 \\
\hline \multirow[t]{2}{*}{ Hanö Bay H26+H32 } & 65.9 & $55^{\circ} 38^{\prime} 7^{\prime \prime}$ & $14^{\circ} 41^{\prime} 62^{\prime \prime}$ & Lu 3084 & $>38000$ & & Unit D gyttja clay & 1,3 \\
\hline & 73.4 & $55^{\circ} 35^{\prime} 38^{\prime \prime}$ & $14^{\circ} 37^{\prime} 96^{\prime \prime}$ & & & & & \\
\hline Gärdslöv & $34.1-34.5$ & $55^{\circ} 28^{\prime}$ & $13^{\circ} 25^{\prime}$ & St 4946 & $32880 \pm 1770$ & $38 \pm 2$ & Gärdslöv beds & 2 \\
\hline Gärdslöv & $34.5-35.0$ & $55^{\circ} 28^{\prime}$ & $13^{\circ} 25^{\prime}$ & St 4274 & $>34000$ & & Gärdslöv beds & 2 \\
\hline Gärdslöv & $34.5-35.0$ & $55^{\circ} 28^{\prime}$ & $13^{\circ} 25^{\prime}$ & St 3158 & $32730 \pm 2800$ & $38 \pm 3$ & Gärdslöv beds & 2 \\
\hline Gärdslöv & $34.9-35.2$ & $55^{\circ} 28^{\prime}$ & $13^{\circ} 25^{\prime}$ & St 4273 & $21305 \pm 3000$ & $25 \pm 4$ & Gärdslöv beds & 2 \\
\hline Gärdslöv & $36.0-36.2$ & $55^{\circ} 28^{\prime}$ & $13^{\circ} 25^{\prime}$ & St 4272 & $>35000$ & & Gärdslöv beds & 2 \\
\hline Gärdslöv & $42.6-42.9$ & $55^{\circ} 28^{\prime}$ & $13^{\circ} 25^{\prime}$ & St 4938 & $22835 \pm 1680$ & $27 \pm 2$ & Gärdslöv beds & 2 \\
\hline Gärdslöv & $52.6-53.0$ & $55^{\circ} 28^{\prime}$ & $13^{\circ} 25^{\prime}$ & St 4271 & $27535 \pm 5000$ & $33 \pm 5$ & Gärdslöv beds & 2 \\
\hline Hyby & $34.5-34.8$ & $55^{\circ} 35^{\prime}$ & $13^{\circ} 16^{\prime}$ & St 4961 & $31425 \pm 5400$ & & Gärdslöv beds & 2 \\
\hline Hyby & $34.5-35.0$ & $55^{\circ} 35^{\prime}$ & $13^{\circ} 16^{\prime}$ & St 3157 & $36995 \pm 2865$ & $42 \pm 3$ & Gärdslöv beds & 2 \\
\hline Hyby & $52.4-53.0$ & $55^{\circ} 35^{\prime}$ & $13^{\circ} 16^{\prime}$ & St 5093 & $31380 \pm 5880$ & & Gärdslöv beds & 2 \\
\hline
\end{tabular}

ago (subunit B), and the deposition of the overlying clay (subunit C) have important implications for the palaeoenvironmental history of the southwestern Baltic during MIS 3. During the Middle Weichselian the Baltic Basin was probably connected to Kattegat via the Esrum/Alnarp valley (Lagerlund 1987; Houmark-Nielsen \& Kjær 2003) (Fig. 1B). This valley is currently sediment-filled but has a bedrock threshold at $c .60 \mathrm{~m}$ b.s.l., which makes it the lowest sill of the Baltic depression. The main sediments in the central and northern parts of the Esrum/Alnarp valley are composed of a fluvial fining-upward sequence referred to as the Grevie sand by Nilsson (1973); this sequence has been correlated with the Gärdslöv beds (Lagerlund 1980) at Gärdslöv (Nilsson 1973) and with the Uranienborg member (Adrielsson 1984) on Ven and Sjælland (Adrielsson 1984; Lagerlund 1987; Houmark-Nielsen 1999; Houmark-Nielsen \& Kjær 2003) (Figs 1B, 4). Bulk radiocarbon dates give ages of $31{ }^{14} \mathrm{C}$ kyr BP (not calibrated owing to very large uncertainties) and $42 \mathrm{kyr}$ $\mathrm{BP}$ for the Grevie sand, and $25 \mathrm{kyr}$ BP to infinite ages for the Gärdslöv beds (Miller 1977) (Table 1), whereas the Uranienborg member in Vejby, north Sjælland, has been OSL-dated to between 32 and $44 \mathrm{kyr}$ BP (Houmark-Nielsen \& Kjær 2003). The mixture of arctic and temperate pollen, palynomorphs and plant fragments found in the Grevie sand and Gärdslöv beds (Holst 1911; Ekström 1953; Miller 1977) indicates reworking of previously deposited sediments, which may also explain the old and infinite radiocarbon ages. The youngest ages are, therefore, believed to be the most reliable (cf. Nilsson 1973). This would imply that the oldest sediments presently found in the Esrum/Alnarp valley were deposited during or after the deposition of the organic sediments in subunit B.

The following tentative depositional model for the sediment succession at Kriegers Flak is therefore proposed. The transition from the lower diamict unit to clay with beds of diamict (subunit A) suggests deposition in a basin close to a retreating ice front from where debris flows and icebergs were released. Higher up in the subunit, sand and gravel grains become scarce and eventually disappear, pointing to a further retreat of the ice front. The benthic foraminifera found at $40 \mathrm{~m}$ b.s.l. in core E02 indicate occasional brackish influences during the deposition of subunit A. At present, however, we are unable to determine whether brackish conditions prevailed throughout subunit A or whether the brackish interval represents a shorter period. Because no indications of an ice advance have been identified in the clay sequence, we suggest that this marine phase probably occurred after the Ristinge Advance (55-50 kyr BP) (Larsen et al. 2009a). The brackish phase identified in subunit A could correspond to sediments from the northeastern part of Kriegers Flak, which indicate boreo-arctic conditions and a brackish environment (Klingberg 1998). Unfortunately, these latter sediments only provided infinite ages (Klingberg 1998), and our correlations therefore remain speculative. A possible correlation may also exist between subunit A and a boreo-arctic, brackish-marine clay identified on Rügen that has tentatively been dated to the Middle Weichselian (Panzig 1997) (Fig. 5), and between subunit A and marine sand in coastal bluffs in western Latvia that has been OSL-dated to $45-43 \mathrm{kyr}$ BP. Because global sea level for the latter half of MIS 3 has been reconstructed at $c$. $80-100 \mathrm{~m}$ b.s.l. (Lambeck \& Chappell 2001; Siddall et al. 2008), our findings of 
Fig. 5. Suggested correlation between Middle Weichselian stratigraphic events in the southwestern Baltic Basin and the Esrum/Alnarp Valley. Data from Adrielsson (1984), Houmark-Nielsen (1994),

Houmark-Nielsen (2008), Houmark-Nielsen \& Kjær (2003), Nilsson (1973), Steinich (1992) and Panzig (1997).

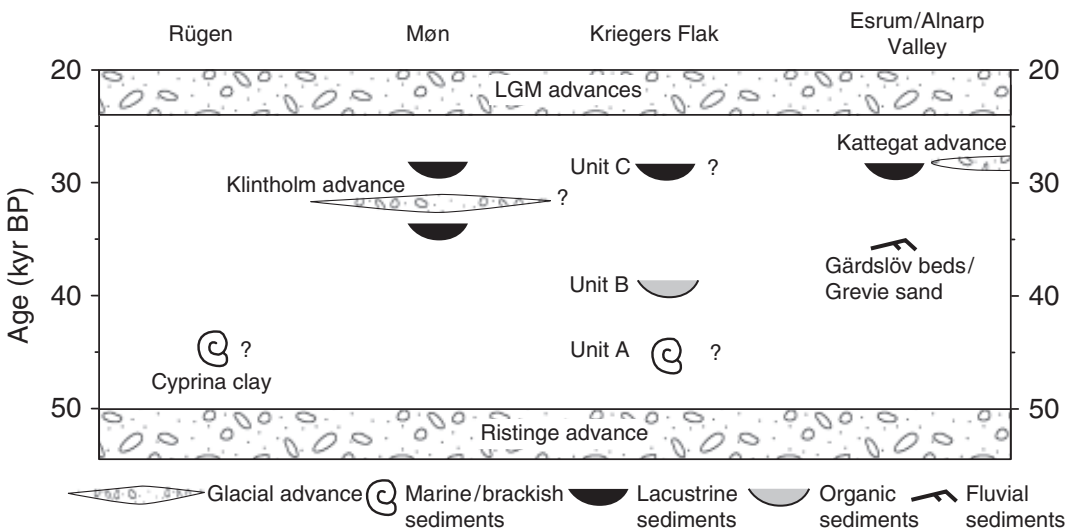

clay (subunit A) was deposited in a partly brackish environment following a deglaciation of the southern Baltic Basin. This interval was followed by falling water levels, which led to the formation of wetlands with small isolated lakes where gyttja and peat were deposited c. $40 \mathrm{kyr}$ BP (subunit B). Fluctuations of the water level are recorded as shifts between clay, peat and gyttja deposition. The upper clay (subunit C) at Kriegers Flak implies a transgression, probably related to the Kattegat advance $c$. $29 \mathrm{kyr}$ BP. The new data from Kriegers Flak, showing significant changes from brackish to lacustrine and terrestrial environments, have regional implications, as they provide a basic framework for reconstructions of the history of the Baltic Basin during MIS 3. However, further investigations, including better chronological constraints, are needed to confirm the scenario presented here, and to provide a better understanding of the sedimentary environment at Kriegers Flak between $c .40$ and c. $29 \mathrm{kyr}$ BP.

detailed correlations difficult at this point.

A transgression is indicated by the renewed deposition of clay on top of subunit B. A likely cause for the transgression is the Kattegat ice advance that flowed from the north into Skagerrak and dammed Kattegat and the Baltic Basin c. 29 kyr BP (Lagerlund 1987; Houmark-Nielsen \& Kjær 2003; Larsen et al. 2009a), which led to the deposition of a fining-upward sequence in the northwestern Esrum/ Alnarp valley (Nilsson 1973; Miller 1977; Lagerlund 1987). The Alabodarna till, which overlies the Uranienborg member on Ven, has been correlated with the Kattegat advance (Adrielsson 1984). This interpretation would indicate the existence of a hiatus between the deposition of the organic sediments at Kriegers Flak c. 41-36 kyr BP and the damming of the Kattegat c. $29 \mathrm{kyr}$ BP (Fig. 5), although it is difficult to estimate the temporal extent of this assumed hiatus until more dates from subunit B are obtained.

\section{Conclusions}

A succession of inorganic and organic sediments and peat was identified between thick till beds in drill cores from Kriegers Flak, southwestern Baltic Sea. The lower
Acknowledgements.- This investigation was made possible by Göran Loman and Vattenfall, who kindly allowed us to analyse the cores retrieved from Kriegers Flak during their survey of the area. The radiocarbon dates were financed by Vattenfall, Crafoord and VR. We are thankful to Svend Funder, who identified the shell fragments. We would also like to thank journal editor Jan A. Piotrowski, guest editor Barbara Wohlfarth and journal reviewers Michael Houmark-Nielsen and Mark Johnson who made thorough and constructive reviews.

\section{References}

Adrielsson, L. 1984: Weichselian lithostratigraphy and glacial environment in the Ven-Glumslöv area, southern Sweden. Ph.D. thesis, Lund University, $120 \mathrm{pp}$.

Andrén, T. \& Wannäs, K. 1988: Late Quaternary development of the Bornholm Gat. In Winterhalter, E. (ed.): The Baltic Sea, 23-29. Geological Survey of Finland, Special Paper 6.

Bjerkéus, M., Gelumbauskaitë, Z., Sturkell, E., Flodén, T. \& Grigelis, A. 1994: Paleochannels in the east central part of the Baltic Proper. Baltica 8, 15-26. the Late Weichselian and Holocene development of the Hanö Bay, southeastern Sweden. Geographia Polonica 55, 51-62.

Björck, S., Dennegård, B. \& Sandgren, P. 1990: The marine stratigraphy of the Hanö Bay, SE Sweden, based on different sediment
Björck, S. \& Dennegård, B. 1988: Preliminary stratigraphic studies on 
stratigraphic methods. Geologiska Föreningens $i$ Stockholm Förhandlingar 112, 265-280.

Clement, A. C. \& Peterson, L. C. 2008: Mechanisms of abrupt climate change of the last glacial period. Reviews of Geophysics 46, RG4002, doi: 10.1029/2006RG000204.

Dansgaard, W., Johnsen, S. J., Clausen, H. B., Dahl-Jensen, D., Gundestrup, N. S., Hammer, C. U., Hvidberg, C. S., Steffensen, J. P., Sveinbjörnsdottir, A. E., Jouzel, J. \& Bond, G. 1993: Evidence for general instability of past climate from a $250-\mathrm{kyr}$ ice-core record. Nature 364, 218-220.

Ekström, G. 1953: Beskrivning till kartbladet Lund. Sveriges Geologiska Undersökning, Serie Ad. 2, 1-102.

Fairbanks, R. G., Mortlock, R. A., Chiu, T. C., Cao, L., Kaplan, A., Guilderson, T. P., Fairbanks, T. W., Bloom, A. L., Grootes, P. M. \& Nadeau, M. J. 2005: Radiocarbon calibration curve spanning 0 to 50,000 years BP based on paired ${ }^{230} \mathrm{Th} /{ }^{234} \mathrm{U} /{ }^{238} \mathrm{U}$ and $\mathrm{C}-14$ dates on pristine corals. Quaternary Science Reviews 24, 1781-1796.

Flodén, T., Bjerkéus, M., Sturkell, E., Gelumbauskaitë, Z., Grigelis, A., Endler, R. \& Lemke, W. 1997: Distribution and seismic stratigraphy of glacially incised valleys in the southern part of the Baltic. In Cato, I. \& Klingberg, F. (eds.): Proceedings of the Fourth Marine Geological Conference - the Baltic, 43-49. Sveriges Geologiska Undersökning, Serie Ca 86.

Hättestrand, M. 2008: Vegetation and climate during Weichselian ice free intervals in northern Sweden - Interpretations from fossil and modern pollen records. Ph.D. thesis, Stockholm University, 118 pp.

Helmens, K. F., Bos, J. A. A., Engels, S., Van Meerbeeck, C. J., Bohncke, S. J. P., Renssen, H., Heiri, O., Brooks, S. J., Seppä, H., Birks, H. J. B. \& Wohlfarth, B. 2007: Present-day temperatures in northern Scandinavia during the last glaciation. Geology 35, 987-990.

Helmens, K. F., Räsänen, M. E., Johansson, P. W., Jungner, H. \& Korjonen, K. I. 2000: The last interglacial-glacial cycle in NE Fennoscandia: a nearly continuous record from Sokli (Finnish Lapland). Quaternary Science Reviews 19, 1605-1623.

Holst, N. O. 1911: Alnarps-floden en svensk "Cromer-flod". Sveriges Geologiska Undersökning, Serie C 237, 1-64.

Houmark-Nielsen, M. 1994: Late Pleistocene stratigraphy, glaciation chronology and Middle Weichselian environmental history from Klintholm, Møn, Denmark. Bulletin of the Geological Society of Denmark 41, 181-202.

Houmark-Nielsen, M. 1999: A lithostratigraphy of Weichselian glacial and interstadial deposits in Denmark. Bulletin of the Geological Society of Denmark 46, 101-114.

Houmark-Nielsen, M. 2003: Signature and timing of the Kattegat Ice Stream: onset of the Last Glacial Maximum sequence at the southwestern margin of the Scandinavian Ice Sheet. Boreas 32, 227-241.

Houmark-Nielsen, M. 2007: Extent and age of Middle and Late Pleistocene glaciations and periglacial episodes in southern Jylland, Denmark. Bulletin of the Geological Society of Denmark 55, 9-35.

Houmark-Nielsen, M. 2008: Testing OSL failures against a regional Weichselian glaciation chronology from southern Scandinavia. Boreas 37, 660-677.

Houmark-Nielsen, M. \& Kjær, K. H. 2003: Southwest Scandinavia, 40-15 kyr BP: palaeogeography and environmental change. Journal of Quaternary Science 18, 769-786.
Kjær, K. H., Lagerlund, E., Adrielsson, L., Thomas, P. J., Murray, A. \& Sandgren, P. 2006: The first independent chronology for Middle and Late Weichselian sediments from southern Sweden and the Island of Bornholm. GFF 128, 209-220.

Klingberg, F. 1998: A late Pleistocene marine clay succession at Kriegers Flak, westernmost Baltic, southern Scandinavia. Journal of Quaternary Science 13, 245-253.

Lagerlund, E. 1980: Litostratigrafisk indelning av Västskånes Pleistocen och en ny glaciationsmodell för Weichsel. University of Lund Department of Quaternary Geology, Report 21, $120 \mathrm{pp}$.

Lagerlund, E. 1987: An alternative Weichselian glaciation model, with special reference to the glacial history of Skåne, South Sweden. Boreas 16, 433-459.

Lambeck, K. \& Chappell, J. 2001: Sea level change through the last glacial cycle. Science 292, 679-686.

Larsen, N. K., Knudsen, K. L., Krohn, C. F., Kronborg, C., Murray, A. S. \& Nielsen, O. B. 2009a: Late Quaternary ice sheet, lake and sea history in southwest Scandinavia - a synthesis. Boreas 38, $732-761$.

Larsen, N. K., Krohn, C. F., Kronborg, C., Nielsen, O. B. \& Knudsen, K. L. 2009b: Lithostratigraphy of the Late Saalian to Middle Weichselian Skærumhede Group in Vendsyssel, northern Denmark. Boreas 38, 762-786.

Mangerud, J., Løvlie, R., Gulliksen, S., Hufthammer, A.-K., Larsen, E. \& Valen, V. 2003: Paleomagnetic correlations between Scandinavian Ice Sheet fluctuations and Greenland DansgaardOeschger events, 45,000-25,000 yr B. P. Quaternary Research 59, 213-222.

Miller, U. 1977: Pleistocene deposits of the Alnarp Valley, southern Sweden - Microfossils and their stratigraphical application. Ph.D. thesis, Lund University, $116 \mathrm{pp}$.

Nilsson, K. 1973: Glacialgeologiska problem i Sydvästskåne. Ph.D. thesis, Lund University, $12 \mathrm{pp}$.

Panzig, W.-A. 1997: The Klüsser site (NW Wittow). In Piotrowski, J. A. (ed.): Excursion guide from field symposium on glacial geology at the Baltic Sea coast in northern Germany, 55-59. The Peribaltic Group, INQUA Commission on Glaciation.

Saks, T., Kalvāns, A. \& Zelěs, V. 2007: Structure and micromorphology of glacial and non-glacial deposits in coastal bluffs at Sensala, Western Latvia. Baltica 20, 19-27.

Seifert, T., Tauber, F. \& Kayser, B. 2001 A high resolution spherical grid topography of the Baltic Sea. Proceedings of the Baltic Sea Science Congress 25-29 November 2001, poster 147. Stockholm, Sweden.

Siddall, M., Rohling, E. J., Thompson, W. G. \& Waelbroeck, C. 2008: Marine isotope stage 3 sea level fluctuations: Data synthesis and new outlook. Reviews of Geophysics 46, RG4003, doi: 10.1029/ 2007RG000226.

Steinich, G. 1992: Die stratigraphische Einordnung der RügenWarmzeit. Zeitschrift für geologische Wissenschaften 20, 125-154.

Ukkonen, P., Arppe, L., Houmark-Nielsen, M., Kjær, K. H. \& Karhu, J. A. 2007: MIS 3 mammoth remains from Sweden - implications for faunal history and glaciation chronology. Quaternary Science Reviews 26, 3081-3098.

Wohlfarth, B. 2009: Ice-free conditions in Fennoscandia during Marine Oxygen Isotope Stage 3? SKB Technical Report TR-09-12, 48 pp. 